\title{
Effects of partially replacing dietary starch with dry glycerol in a lactating cow diet on ruminal fermentation during continuous culture
}

\author{
D. E. Rico, Y.-H. Chung, C. M. Martinez, T. W. Cassidy, K. S. Heyler, and G. A. Varga ${ }^{1}$ \\ Department of Dairy and Animal Science, The Pennsylvania State University, University Park 16802
}

\begin{abstract}
The effects of dry glycerol as a partial replacement for dietary starch in a lactating cow diet on ruminal fermentation and bacterial protein synthesis were evaluated using 4 single-flow, continuous-culture fermentors (ranging from 1,015 to $1,040 \mathrm{~mL}$ in volume). The basal lactating cow diet was formulated to have partial contents of dietary starch provided from a corn starch supplement [at $12.37 \%$ diet dry matter (DM)], which was partially or completely replaced by a dry glycerol product. Both the corn starch supplement and dry glycerol product contained $65 \%$ of pure corn starch or glycerol, respectively. The final inclusion rate for pure glycerol was at $0,3,5$, or $8 \%$ of $\mathrm{DM}$ in the basal diet. The experiment was conducted using a $4 \times$ 4 Latin square design with four 9-d periods, with the first $6 \mathrm{~d}$ for adaptation and last $3 \mathrm{~d}$ for sampling. Fermentors were inoculated with $1 \mathrm{~L}$ of ruminal fluid and $25 \mathrm{~g}$ of ruminal digesta from a ruminally cannulated cow receiving a lactation total mixed ration $(16 \%$ crude protein, $32 \%$ neutral detergent fiber, and $25 \%$ starch; DM basis). Each fermentor was fed $75 \mathrm{~g}$ of DM of its respective experimental diet daily in 3 equal portions (at 0800, 1400, and $2000 \mathrm{~h}$ ). Liquid dilution rate of the fermentors was maintained at $10 \% / \mathrm{h}$ and solids retention time was set at $24 \mathrm{~h}$. Fermentation fluid and the effluent from each fermentor were sampled once daily (at $1330 \mathrm{~h}$ ) from d 7 to 9 of each period and pooled by period. Postprandial ruminal fermentation was studied by sampling the fermentors hourly for $5 \mathrm{~h}$ after the $0800 \mathrm{~h}$ feeding on d 9 of each period. The total fermentation contents were harvested at the end of the period for estimations of bacterial protein synthesis. Replacing corn starch with dry glycerol linearly increased the proportions of propionate and valerate at the expense of acetate in the fermentation fluid measured daily or for the first $5 \mathrm{~h}$ after feeding. Replacing corn starch with dry glycerol also linearly increased the digestibility of
\end{abstract}

Received October 17, 2011.

Accepted January 24, 2012.

${ }^{1}$ Corresponding author: gvarga@psu.edu dietary neutral detergent fiber without a change on the flow or efficiency of bacterial protein synthesis during continuous culture. Results indicate that glycerol as a dry product can replace dietary starch as corn starch at a level of up to $8 \%$ of DM in the diet without negatively affecting ruminal fermentation and digestibility during continuous culture.

Key words: dry glycerol, dietary starch, ruminal fermentation, continuous culture

\section{INTRODUCTION}

Glycerol is an important precursor for $s n$-glycerol3-phosphate, which is a carbon skeleton for gluconeogenesis (Lin, 1977). Glycerol is a main component of lipids such as triglycerides and phospholipids and it is used as a substrate for glucose synthesis in mammals. Glycerol has been used in ruminants as a treatment for ketosis since the 1950s (Griffiths, 1952; Johnson, 1954) and more recently, it has been evaluated as an ingredient in diets for ruminants (Schröder and Südekum, 1999; Donkin et al., 2009; Carvalho et al., 2011).

Glycerol is rapidly fermented in the rumen, and maximal rates of glycerol disappearance seem to be reached during the first few hours of incubation in the rumen and increased with the amount administered (Garton et al., 1961; Remond et al., 1993). A fraction of the glycerol fermented in the rumen is converted into propionic acid (Hobson and Mann, 1961), which in turn, serves as a glucogenic precursor, supplying 32 to $73 \%$ of the glucose demands in ruminants (Seal and Reynolds, 1993). Fermentation of glycerol increased the relative proportions of propionic and butyric acids at the expense of acetic acid both in vitro and in vivo (Remond et al., 1993; Kijora et al., 1998; Wang et al., 2009). In vitro fermentation of glycerol has shown that growth of cellulolytic bacteria such as Ruminococcus flavefaciens and Fibrobacter succinogenes was inhibited when glycerol was added at 2 to $5 \%$ of the medium with cellobiose as the main substrate (Roger et al., 1992). In agreement with this, increasing dietary glycerol (Donkin et al., 2009) tended to decrease apparent digestibility of NDF relative to control when fed between 5 and $15 \%$ of ration DM. 
Energy content of various glycerol sources is dependent on their purity (i.e., glycerol content) and has been reported to be between 1.98 and $2.27 \mathrm{Mcal}$ of $\mathrm{NE}_{\mathrm{L}} / \mathrm{kg}$ when fed in combination with a high or a low starch concentrate, respectively (Schröder and Südekum, 1999). These values are close to that of corn, which is approximately $2.0 \mathrm{Mcal}$ of $\mathrm{NE}_{\mathrm{L}} / \mathrm{kg}$ (NRC, 2001). Glycerol is usually found in a liquid form and is obtained as a byproduct from biodiesel production (Ma and Hanna, 1999). However, glycerol in a dry form may be more versatile for uses compared with glycerol in a liquid form. A dry glycerol product, used as a glucogenic substrate, was reported to improve the metabolic status of cows in early lactation (Chung et al., 2007).

Efficacies of glycerol, as a dry product, in replacing dietary starch on ruminal fermentation have not been extensively evaluated. We hypothesized that partial replacements of dietary starch with glycerol at a level of up to $8 \%$ (diet DM) in ruminant diets would not negatively affect ruminal fermentation. The objectives of this experiment were to determine the effects of increasing levels of dry glycerol as a partial replacement for dietary starch, such as corn starch, in a lactating cow diet on ruminal fermentation, diet digestibility, and bacterial protein synthesis during continuous culture.

\section{MATERIALS AND METHODS}

\section{Experimental Design and Dietary Treatments}

The effects of partially replacing dietary starch with glycerol in a lactating cow diet on in vitro ruminal fermentation were studied using a $4 \times 4$ Latin square design with 4 single-flow, continuous fermentors and four 9-d experimental periods. A basal diet (Tables 1 and 2) was formulated to provide adequate ME and MP for a $660-\mathrm{kg}$ cow producing $38 \mathrm{~kg} / \mathrm{d}$ of milk containing $3.5 \%$ fat and $3.3 \%$ protein and assuming a DMI of $25 \mathrm{~kg} / \mathrm{d}$ using the Cornell-Penn-Miner System (CPM Dairy, Version 3.0.4a; Cornell University, Ithaca, NY; University of Pennsylvania, Kennett Square, PA; and William H. Miner Agricultural Research Institute, Chazy, NY). This basal lactating cow diet was also formulated to have partial contents of dietary starch provided from a corn starch supplement, which was partially or completely (at $0,4.65,7.72$, or $12.37 \%$ of diet DM) replaced by a dry glycerol product. Both the corn starch supplement and dry glycerol product (Phoderush; Phodé SA, Albi Terssac, France; $\mathrm{NE}_{\mathrm{L}}=2.6 \mathrm{Mcal} / \mathrm{kg}$ of $\mathrm{DM}$ ) contained $65 \%$ pure corn starch or glycerol, respectively. The final inclusion rate for pure glycerol was at $0,3,5$, or $8 \%$ of DM in the basal diet. Extrapolation of these inclusion levels to an animal eating $28 \mathrm{~kg}$ of $\mathrm{DM} / \mathrm{d}$ would be equivalent to $0,0.75,1.25$, and $2.0 \mathrm{~kg} / \mathrm{d}$ of glycerol for
Table 1. Ingredient composition of the basal $\operatorname{diet}^{1}$

\begin{tabular}{lc}
\hline Ingredient & $\begin{array}{c}\% \text { of } \\
\text { diet DM }\end{array}$ \\
\hline Corn silage $^{2}$ & 34.9 \\
Ground corn $_{\text {Canola meal }}$ & 7.3 \\
Alfalfa haylage $^{3}$ & 8.8 \\
Roasted soybeans $^{\text {Extruded soybeans }}$ & 8.8 \\
Cottonseed hulls $^{4}$ & 10.1 \\
Grass hay/straw $^{4}$ & 3.9 \\
Mineral and vitamin mix $^{5}$ & 4.6 \\
& 6.0 \\
\end{tabular}

${ }^{1}$ Ingredient composition presented did not include the $12.37 \%$ of diet DM for the corn starch supplement, dry glycerol product, or both.

${ }^{2}$ Contained $37.8 \%$ DM, $7.2 \%$ CP, $49 \%$ soluble protein (\% of CP), and $38.8 \% \mathrm{NDF}$.

${ }^{3}$ Contained $43.0 \% \mathrm{DM}, 18.9 \% \mathrm{CP}, 60 \%$ soluble protein (\% of CP), and $42.5 \%$ NDF.

${ }^{4}$ Contained $89.3 \%$ DM, $5.8 \%$ CP, $28.9 \%$ soluble protein (\% of CP), and $68.8 \% \mathrm{NDF}$.

${ }^{5}$ Contained $11 \%$ CP, $18 \%$ NDF, $5.1 \%$ fat, $14 \% \mathrm{Ca}, 0.35 \% \mathrm{P}, 4.6 \% \mathrm{Mg}$, $0.42 \% \mathrm{~K}, 0.3 \% \mathrm{~S}, 1,071 \mathrm{mg}$ of $\mathrm{Mn} / \mathrm{kg}, 357 \mathrm{mg}$ of $\mathrm{Cu} / \mathrm{kg}, 1,085 \mathrm{mg}$ of $\mathrm{Zn} / \mathrm{kg}, 6.66 \mathrm{mg}$ of Se $/ \mathrm{kg}, 6.4 \%$ salt (DM basis), 262,101 IU of vitamin $\mathrm{A} / \mathrm{kg}$ of DM, $65,421 \mathrm{IU}$ of vitamin $\mathrm{D} / \mathrm{kg}$ of DM, and 1,912 IU of vitamin $\mathrm{E} / \mathrm{kg}$ of DM.

the $0,3,5$, and $8 \%$ inclusion rate, respectively. The dry glycerol product contained $33 \%$ ash and $<2 \%$ glycerol FA esters, water, negligible amounts of salt and methanol, and flavoring substances other than glycerol and was stabilized using silica as a carrier. Pure corn starch was mixed with silica to obtain a $65 \%$ purity starch supplement, allowing for a 1:1 (DM basis) comparison of glycerol and starch.

\section{Continuous-Culture Operation and Sampling}

Four single-flow, continuous-culture fermentors similar to that described by Hoover et al. (1989) were used. Fermentors ranged from 1,015 to $1,040 \mathrm{~mL}$ in volume. Inocula of ruminal fluid and digesta were obtained from a single cow consuming a lactation TMR (forage:concentrate $=55: 45 ; 16 \% \mathrm{CP}, 32 \% \mathrm{NDF}$, and $25 \%$ starch; DM basis). The cow was cared for and its rumen contents collected following protocols approved by The Pennsylvania State University Animal Care and Use Committee.

Each fermentor was inoculated with $1,000 \mathrm{~mL}$ of ruminal fluid and $25 \mathrm{~g}$ of ruminal digesta within $15 \mathrm{~min}$ of collection. An artificial saliva buffer solution (McDougall, 1948) was infused into the fermentors continuously at a liquid dilution rate of $10 \% / \mathrm{h}$, with a solid retention time of $24 \mathrm{~h}$ (Crawford et al., 1980). Each fermentor was fed its assigned diet at a rate of $75 \mathrm{~g}$ of $\mathrm{DM} / \mathrm{d}$ in 3 equal feedings at 0800,1400 , and $2000 \mathrm{~h}$ for $9 \mathrm{~d}$. The basal diet was dried for $48 \mathrm{~h}$ at $55^{\circ} \mathrm{C}$ in a forced-air oven and ground in a Wiley mill (A. H. Thomas Co., 
Philadelphia, PA) through a 4-mm mesh screen before it was mixed with the dry glycerol product and corn starch supplement. The dry glycerol product and corn starch supplement were weighed separately and top dressed onto the basal diet daily.

Daily, the total effluent volume from each fermentor was recorded at $1330 \mathrm{~h}$ ( $5.5 \mathrm{~h}$ after the 0800 -h feeding) and from d 7 to 9 of each period, $1 \mathrm{~L}$ of the effluent from each fermentor was subsampled, composited by period, and freeze dried for analysis of DM, ash, N, NDF, and purines. Lyophilization was carried out in a freeze dryer (model Ultra 35-XL; Virtis Co. Inc., Gardiner, NY). Fermentation fluid $(15 \mathrm{~mL})$ from each fermentor was also sampled from d 7 to 9 of each period at $1330 \mathrm{~h}$ and pooled for analysis of ammonia-N and VFA concentrations (Yang and Varga, 1989). Fermentation fluid $\mathrm{pH}$ was not artificially controlled and was recorded at each feeding.

On d 9 of each period, fermentation fluid $(15 \mathrm{~mL})$ from each fermentor was serially sampled at $0,1,2$, 3,4 , and $5 \mathrm{~h}$ after the $0800-\mathrm{h}$ feeding for analysis of ammonia-N and VFA concentrations. After the serial samplings (at $1330 \mathrm{~h}$ ), total fermentation content from each fermentor was used to harvest microbial protein (Vázquez-Añón et al., 2001). Samples for bacteria were freeze dried and analyzed for DM, N, and purine (Bargo et al., 2003).

\section{Laboratory Analysis and Calculations}

Samples of the freeze-dried effluents and the basal diet were analyzed for DM, ash, N, NDF, ADF, and purine content. Dry matter content was determined by drying at $135^{\circ} \mathrm{C}$ for $2 \mathrm{~h}(\mathrm{AOAC}, 2005)$. Ash content was determined by placing samples in a muffle furnace at $600^{\circ} \mathrm{C}$ for $2 \mathrm{~h}$ (AOAC, 2005). Contents of $\mathrm{N}$ were determined by combustion (Leco Instruments Inc., St. Joseph, MI) and multiplied by 6.25 to obtain the contents for CP (AOAC, 2005). Acid detergent fiber and NDF were determined using the Ankom A200 Filter Bag Technique (Ankom Technology, Macedon, NY) according to Van Soest et al. (1991) with heat-stable amylase and sodium sulfite used in the NDF procedure. Purine content was estimated according to Zinn and Owens (1986).

Flows $(\mathrm{g} / \mathrm{d})$ of dietary and bacterial $\mathrm{N}$ in the fermentor effluent were calculated using the following equations:

$$
\mathrm{g} \text { of effluent dietary } \mathrm{N}=(\mathrm{g} \text { of effluent NAN })
$$$$
\text { - (g of effluent bacterial } \mathrm{N}) \text {; }
$$

$$
\begin{gathered}
\mathrm{g} \text { of effluent bacterial } \mathrm{N}=(\mathrm{g} \text { of effluent total } \mathrm{N}) \\
\times(\% \text { of bacterial } \mathrm{N} \text { in effluent total } \mathrm{N}) .
\end{gathered}
$$

\section{Statistical Analysis}

The average of the $6 \mathrm{pH}$ readings taken from $\mathrm{d} 7$ to 8 of each period were used to represent the fermentation fluid $\mathrm{pH}$ for each treatment at each period. Average ammonia and VFA concentrations for the fermentation fluid treatment values were calculated from the average of the samples collected at $1330 \mathrm{~h}$ on d 7 to 9 of each period.

Effects of increasing levels of glycerol in the diets on ruminal fermentation, bacterial protein synthesis, and nutrient digestion were analyzed using the MIXED procedure of SAS (SAS Institute, 1999). Fermentor was the experimental unit for all variables. For measurements taken daily and pooled by period, the model included period and treatment as the fixed effects. For measurements taken hourly (i.e., postprandial concentrations of ammonia-N and VFA), the model included the fixed effects of period, treatment, sampling time, and the interaction of treatment by sampling time. The interaction of treatment by period was not significant and, therefore, not included in the model. Time of sampling (hour) was used in the REPEATED statement. Timeseries covariance structure was modeled using various options, and the best time-series covariance structure was selected based on the lowest Akaike and Bayesian information criteria. Orthogonal polynomial contrasts were used to test the linear and quadratic dependable variable responses to increasing levels of glycerol in the diets. Because the doses of glycerol evaluated $(0,3,5$, and $8 \%$ diet $\mathrm{DM}$ ) were not equally spaced, orthogonal polynomial contrasts were constructed according to the method described by Robson (1959). Differences among treatments were evaluated by comparing the treatment least squares means and using the PDIFF option with the Tukey adjustment in the model statement when a significant effect of treatment existed for that variable. Significance was declared at $P<0.05$ and trends at $P$ $<0.10$.

\section{RESULTS AND DISCUSSION}

\section{Ruminal $\mathrm{pH}$ and VFA}

Fermentation fluid $\mathrm{pH}$ and VFA profile in response to increasing levels of glycerol in the diet are reported in Table 3. Fermentation fluid $\mathrm{pH}$ was unaffected by increasing doses of glycerol in the diet, averaging 6.49. In agreement with our observations, Khalili et 
Table 2. Chemical composition of the basal $\operatorname{diet}^{1}$

\begin{tabular}{|c|c|}
\hline Item & $\begin{array}{l}\% \text { of DM, unless } \\
\text { otherwise stated }\end{array}$ \\
\hline $\mathrm{CP}$ & 17.9 \\
\hline Soluble CP, $\%$ of CP & 27.2 \\
\hline NDF & 34.5 \\
\hline $\mathrm{ADF}$ & 23.1 \\
\hline Ether extract & 6.1 \\
\hline Starch & 23.8 \\
\hline Sugar & 4.4 \\
\hline $\mathrm{NFC}^{2}$ & 35.8 \\
\hline Ash & 5.7 \\
\hline $\mathrm{NE}_{\mathrm{L}},{ }^{3} \mathrm{Mcal} / \mathrm{kg}$ & 1.86 \\
\hline $\mathrm{Ca}$ & 0.91 \\
\hline $\mathrm{P}$ & 0.37 \\
\hline $\mathrm{Mg}$ & 0.36 \\
\hline $\mathrm{K}$ & 1.28 \\
\hline $\mathrm{Na}$ & 0.24 \\
\hline $\mathrm{Fe}, \mathrm{mg} / \mathrm{kg}$ & 174 \\
\hline $\mathrm{Mn}, \mathrm{mg} / \mathrm{kg}$ & 84 \\
\hline $\mathrm{Zn}, \mathrm{mg} / \mathrm{kg}$ & 88 \\
\hline $\mathrm{Cu}, \mathrm{mg} / \mathrm{kg}$ & 24 \\
\hline
\end{tabular}

${ }^{1}$ The basal diet did not include the corn starch supplement, dry glycerol product, or both.

${ }^{2}$ Nonfiber carbohydrates $=100-(\mathrm{CP}+\mathrm{NDF}+$ ether extract + ash $)$. ${ }^{3}$ Estimated based on NRC (2001).

al. (1997) found no effect on ruminal $\mathrm{pH}$ when liquid glycerol was used to replace $3.6 \%$ of barley in grass silage-based diets (approximately $63 \%$ of ration DM) fed to dairy cows. However, Wang et al. (2009) reported a linear decrease in $\mathrm{pH}$ as inclusion of supplemental glycerol increased $(0,1.1,2.2$, and $3.3 \%$ of DMI) in corn stover-based diets (forage:concentrate $=60: 40$ ) fed to Simmental steers. Similarly, Mach et al. (2009) found that feeding $8 \%$ of the concentrate DM as glycerol in high-grain diets (approximately $85 \%$ of diet DM) significantly decreased ruminal $\mathrm{pH}$, a change probably driven by the tendency for a higher total VFA concentration. The decrease in the postprandial ruminal $\mathrm{pH}$ of steers was more pronounced when glycerol of varying degrees of purity partially replaced wheat starch, suggesting faster ruminal degradation of glycerol than of starch (Schröder and Südekum, 1999).

In the present experiment, total VFA concentration was not affected by increasing doses of glycerol in the diet, averaging $88.1 \mathrm{mmol} / \mathrm{L}$. The lack of effect of glycerol on concentrations of total VFA may explain the concomitant lack of response on ruminal $\mathrm{pH}$ by glycerol. Wang et al. (2009) reported a linear increase in total VFA concentration and a linear decrease in ruminal $\mathrm{pH}$ with increasing levels of liquid glycerol in the diets. However, in their experiment, glycerol was supplemented to the control ration, replacing all DM and not starch specifically. Our data indicate that when it was used to replace dietary starch as corn starch, glycerol did not affect total VFA concentration or $\mathrm{pH}$ in the fermentation fluid.

The proportion of propionate increased and acetate decreased linearly $(P<0.01)$ with increasing levels of glycerol in the diet. The linear increase in the proportion of propionate in the fermentation fluid by glycerol indicated that glycerol was partly metabolized to propionate during continuous culture. Our results are in agreement with studies both in vivo (Khalili et al., 1997; Kijora et al., 1998; Carvalho et al., 2011) and in vitro (Bergner et al., 1995; Trabue et al., 2007), suggesting that including glycerol in the diets promoted a more glucogenic fermentative pattern.

Table 3. Effects of replacing corn starch with dry glycerol in a lactating cow diet on ruminal pH and VFA during continuous culture

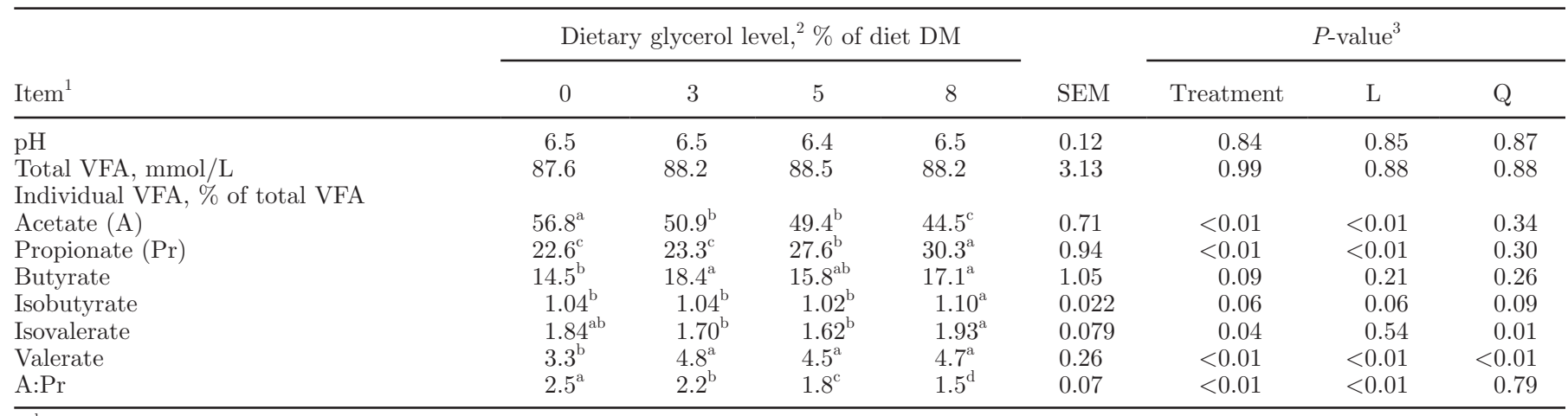

${ }^{\mathrm{a}-\mathrm{d}}$ Means within a row lacking a common superscript differ $(P<0.05)$.

${ }^{1}$ Measured from the composited effluent samples taken from d 7 to 9 of each period.

${ }^{2} 0 \%$ glycerol treatment $=12.37 \%$ corn starch supplement and $0 \%$ dry glycerol product; $3 \%$ glycerol treatment $=7.72 \%$ corn starch supplement and $4.65 \%$ dry glycerol product; $5 \%$ glycerol treatment $=4.65 \%$ corn starch supplement and $7.72 \%$ dry glycerol product; $8 \%$ glycerol treatment $=0 \%$ corn starch supplement and $12.37 \%$ dry glycerol product. Both corn starch supplement and dry glycerol product contained $65 \%$ pure corn starch and glycerol, respectively.

${ }^{3}$ Linear (L) or quadratic (Q) effect of increasing levels of dry glycerol in the diets. 
Table 4. Effect of replacing corn starch with dry glycerol in a lactating cow diet on ruminal VFA for the first $5 \mathrm{~h}$ after feeding during continuous culture

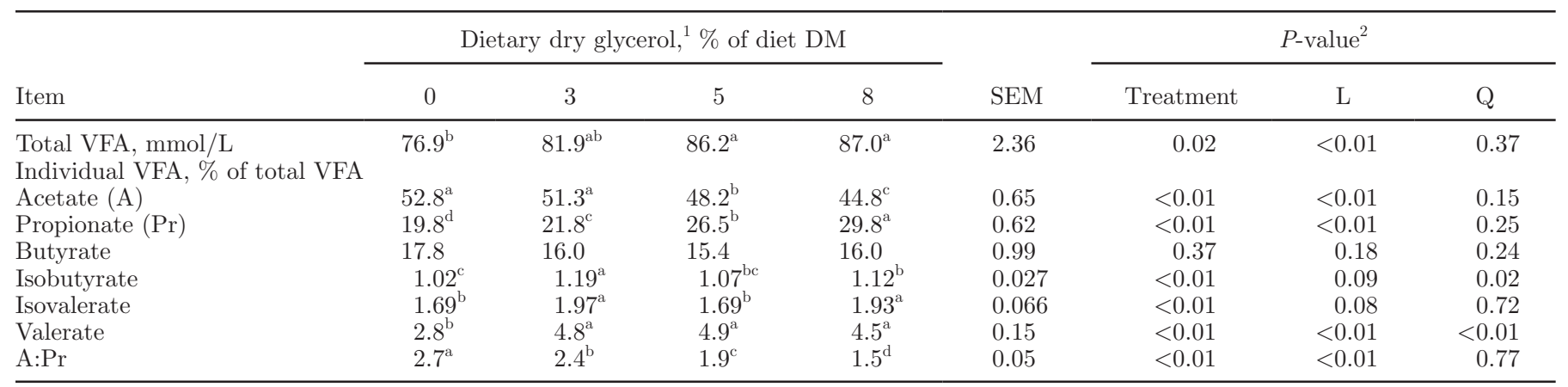

${ }^{\mathrm{a}-\mathrm{d}}$ Means within a row lacking a common superscript differ $(P<0.05)$.

${ }^{1} 0 \%$ glycerol treatment $=12.37 \%$ corn starch supplement and $0 \%$ dry glycerol product; $3 \%$ glycerol treatment $=7.72 \%$ corn starch supplement and $4.65 \%$ dry glycerol product; $5 \%$ glycerol treatment $=4.65 \%$ corn starch supplement and $7.72 \%$ dry glycerol product; $8 \%$ glycerol treatment $=0 \%$ corn starch supplement and $12.37 \%$ dry glycerol product. Both corn starch supplement and dry glycerol product contained $65 \%$ pure corn starch and glycerol, respectively.

${ }^{2}$ Linear (L) or quadratic (Q) effect of increasing levels of dry glycerol in the diets.

Khalili et al. (1997) reported increased proportions of butyrate by replacing $3.6 \%$ of barley with glycerol in diets for dairy cows. Remond et al. (1993) reported marked increases in butyrate proportions by infusing both 240 and $1,200 \mathrm{~g}$ of glycerol into the rumen of dry cows, equivalent to approximately 3 and $13 \%$ of the DMI, respectively. However, in the current study, the proportion of butyrate only tended $(P=0.09)$ to increase with increasing levels of glycerol in the diet.

A quadratic response was observed on the proportions of isovalerate $(P=0.01)$ and isobutyrate $(P=$ $0.09)$, where replacing corn starch with glycerol at $8 \%$ of diet DM significantly increased the proportions of these iso-acids. In contrast to our study, Kijora et al. (1998) reported a reduction in iso-acids (isobutyrate and isovalerate) when $400 \mathrm{~g} / \mathrm{d}$ (equivalent to $10 \%$ of DMI) of glycerol was infused into the rumen of bulls $(\mathrm{n}=2)$.

The proportion of valerate in the fermentation fluid linearly increased with increasing levels of glycerol in the diet. Valerate is synthesized from propionate and acetate in the rumen (Hungate, 1966), and it is likely that an increase in propionate proportion also increased the proportion of valerate in the fermentation fluid in this study. A concurrent increase in the proportions of propionate and valerate was reported when barley was substituted for glycerol in grass silage-based diets (Khalili et al., 1997).

\section{Postprandial Ruminal VFA}

Postprandial VFA profile in the fermentation fluid is presented in Table 4. Increasing the level of replacement of dietary starch with glycerol in the diet signifi- cantly affected the VFA profile in vitro, but this effect of glycerol on in vitro VFA was consistent throughout the measurement period (no treatment by time interaction; data not shown).

Concentrations of total VFA were increased linearly $(P<0.05)$ with increasing levels of glycerol in the diet. Remond et al. (1993) reported increased total VFA concentrations during the first $6 \mathrm{~h}$ after incubating glycerol (approximately 15\% of DM) in fermentors fed cellulose but not in those fed starch. As average total VFA concentrations (Table 3) were not affected by doses of glycerol, it seems that this increase in total VFA is only postprandial and does not reflect the overall effect over a 24-h period. Postprandial proportions of acetate were decreased and propionate and valerate increased and the subsequent ratios of acetate to propionate decreased linearly with increasing levels of glycerol in the diet. The proportion of butyrate was not affected by glycerol. The shift toward to a more glucogenic fermentative pattern in the fermentation fluid of this study was in agreement with Bergner et al. (1995) in which starch was replaced with glycerol in vitro.

\section{Nitrogen Metabolism}

Metabolism of $\mathrm{N}$ and flow and efficiency of bacterial protein synthesis are reported in Table 5. The concentration of ammonia- $\mathrm{N}$ in the fermentation fluid and flow (as $\mathrm{g} / \mathrm{d}$ ) of ammonia- $\mathrm{N}$ in the effluent were increased only at $8 \%$ inclusion rate of glycerol. It is likely that ammonia accumulated at the higher level of glycerol inclusion due to increased deamination or peptidolysis (Leng and Nolan, 1984; Eschenlauer et al. 2002). Deamination could partly explain the increases 
Table 5. Effects of replacing corn starch with dry glycerol in a lactating cow diet on $\mathrm{N}$ flow and bacterial protein synthesis during continuous culture

\begin{tabular}{|c|c|c|c|c|c|c|c|c|}
\hline Item $^{1}$ & \multicolumn{4}{|c|}{ Dietary dry glycerol, ${ }^{2} \%$ of diet DM } & SEM & \multicolumn{3}{|c|}{$P$-value ${ }^{3}$} \\
\hline Nitrogen input from diet, $\mathrm{g} / \mathrm{d}$ & 2.2 & 2.2 & 2.3 & 2.3 & 0.04 & 0.45 & 0.18 & 1.00 \\
\hline Bacterial N, \% of bacterial DM & 7.5 & 8.7 & 8.0 & 8.0 & 0.20 & 0.85 & 0.64 & 0.53 \\
\hline Effluent bacterial N, \% of NAN & 65.6 & 62.1 & 64.1 & 64.1 & 3.33 & 0.91 & 0.84 & 0.63 \\
\hline \multicolumn{9}{|l|}{ Daily $\mathrm{N}$ flow in effluent } \\
\hline $\mathrm{NAN}, \mathrm{g} / \mathrm{d}$ & 1.5 & 1.5 & 1.5 & 1.5 & 0.04 & 0.97 & 0.80 & 0.86 \\
\hline Dietary $\mathrm{N},{ }^{5} \mathrm{~g} / \mathrm{d}$ & 0.51 & 0.54 & 0.52 & 0.52 & 0.06 & 0.97 & 0.87 & 0.78 \\
\hline $\begin{array}{l}\text { Bacterial efficiency, } \mathrm{g} \text { of bacterial } \\
\mathrm{N} / \mathrm{kg} \text { of DM digested }\end{array}$ & 24.0 & 22.5 & 21.8 & 22.1 & 1.05 & 0.47 & 0.21 & 0.40 \\
\hline
\end{tabular}

${ }^{\mathrm{a}, \mathrm{b}}$ Means within a row lacking a common superscript differ $(P<0.05)$.

${ }^{1}$ Averaged from the daily effluent samples taken from d 7 to 9 of each period.

${ }^{2} 0 \%$ glycerol treatment $=12.37 \%$ corn starch supplement and $0 \%$ dry glycerol product; $3 \%$ glycerol treatment $=7.72 \%$ corn starch supplement and $4.65 \%$ dry glycerol product; $5 \%$ glycerol treatment $=4.65 \%$ corn starch supplement and $7.72 \%$ dry glycerol product; $8 \%$ glycerol treatment $=0 \%$ corn starch supplement and $12.37 \%$ dry glycerol product. Both corn starch supplement and dry glycerol product contained $65 \%$ pure corn starch and glycerol, respectively.

${ }^{3}$ Linear (L) or quadratic (Q) effect of increasing levels of dry glycerol in the diets.

${ }^{4}$ Effluent bacterial $\mathrm{N}(\mathrm{g} / \mathrm{d})=(\mathrm{g}$ of effluent total $\mathrm{N}) \times(\%$ of bacterial $\mathrm{N}$ in effluent total $\mathrm{N})$.

${ }^{5}$ Effluent dietary $\mathrm{N}(\mathrm{g} / \mathrm{d})=(\mathrm{g}$ of effluent $\mathrm{NAN})-(\mathrm{g}$ of effluent bacterial $\mathrm{N})$.

in iso-acids (i.e., Table 3) and a concomitant increase in ammonia at the highest level of glycerol inclusion observed in the present study. It has been previously reported that inclusion of glycerol in the diet decreased incorporation of $\mathrm{N}$ into bacteria (Bergner et al., 1995; Kijora et al., 1998); however, increasing levels of glycerol in the diet had no effects on the flow and efficiency of bacterial protein synthesis during continuous culture in the present study.

\section{Nutrient Digestibility}

Digestibility of DM, OM, and NDF increased linearly $(P<0.01)$ with increasing levels of glycerol in the diet (Table 6). Previously, in an in vitro study, Roger et al. (1992) reported an inhibitory effect of glycerol on the growth and activity of cellulolytic bacteria when cellobiose was the only energy source in the medium. The increased NDF digestibility in the glycerol treatments supports the idea that such an inhibition of cellulolytic bacteria by glycerol did not take place in the current study. It is possible that the inhibitory effect of glycerol on cellulolytic bacteria reported by Roger et al. (1992) was diet dependent. Cellulolytic bacteria require ammonia as the primary N source for growth (Bryant, 1973) as well as iso-acids as carbon skeletons for synthesis of branched-chain AA (Allison et al., 1962). It has been suggested that an increased availability of ammonia to rumen microbes can improve plant cell wall degradation (Van Soest, 1982). In addition, supplementation of iso-acids in vitro has been shown to increase degradation of fiber and to promote bacterial growth (Gorosito et al., 1985). The observed increases in NDF digestibility in the present study is in line with the observed increases in ammonia and iso-acids at the highest level of glycerol inclusion; both factors may have played a role in increasing fiber digestibility.

In agreement with our results, Donkin et al. (2009) reported an increased apparent total-tract digestibility of DM and OM by replacing corn with glycerol up to $15 \%$ (diet DM) in diets (forage:concentrate approximately 55:45) for lactating dairy cows. However, in their study, apparent digestibility of NDF tended to decrease at $5 \%$ glycerol relative to control. Discrepancies on the effects of glycerol on NDF digestibility were perhaps due to different dietary and experimental conditions in the study of Donkin et al. (2009) and the current study. Other previous studies reported no effects of glycerol, as a replacement for starch in diets, on total-tract digestibility of OM, NDF (Khalili et al., 1997; Schröder and Südekum, 1999), DM, and N (Khalili et al., 1997), suggesting that glycerol inclusion in lactating dairy cow diets has no detrimental effects on digestibility.

\section{CONCLUSIONS}

Results from the present study indicate that glycerol as a dry product can replace dietary starch, such as corn starch, at a level up to $8 \%$ of DM in the diet without negatively affecting ruminal fermentation during 
Table 6. Effects of replacing corn starch with dry glycerol in a lactating cow diet on nutrient digestibility during continuous culture

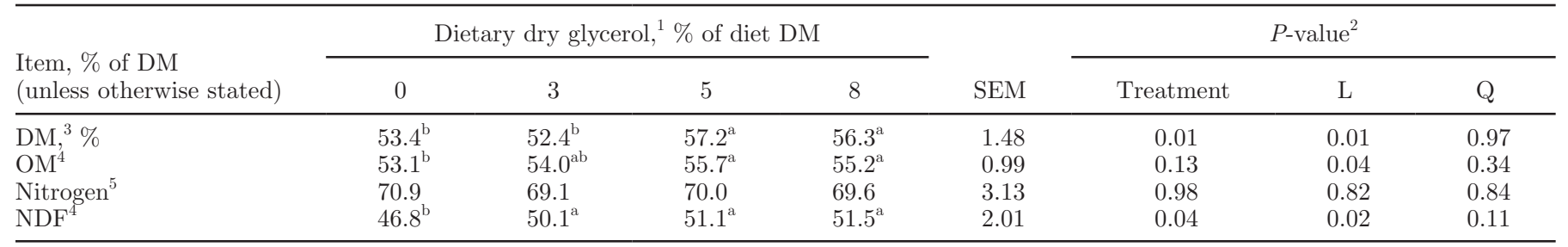

$\overline{\mathrm{a}, \mathrm{b}}$ Means within a row lacking a common superscript differ $(P<0.05)$.

${ }^{1} 0 \%$ glycerol treatment $=12.37 \%$ corn starch supplement and $0 \%$ dry glycerol product; $3 \%$ glycerol treatment $=7.72 \%$ corn starch supplement and $4.65 \%$ dry glycerol product; $5 \%$ glycerol treatment $=4.65 \%$ corn starch supplement and $7.72 \%$ dry glycerol product; $8 \%$ glycerol treatment $=0 \%$ corn starch supplement and $12.37 \%$ dry glycerol product. Both corn starch supplement and dry glycerol product contained $65 \%$ pure corn starch and glycerol, respectively.

${ }^{2}$ Linear (L) or quadratic (Q) effect of increasing levels of dry glycerol in the diets.

${ }^{3}$ True DM digestibility $(\%)=[\mathrm{g}$ of dietary DM - (g of effluent DM - g of bacterial DM $\left.)\right] \div(\mathrm{g}$ of dietary DM $) \times 100$.

${ }^{4}$ Apparent digestibility.

${ }^{5}$ True $\mathrm{N}$ digestibility $(\%)=[\mathrm{g}$ of dietary $\mathrm{N}-(\mathrm{g}$ of effluent $\mathrm{N}-\mathrm{g}$ of bacterial $\mathrm{N})] \div(\mathrm{g}$ of dietary $\mathrm{N}) \times 100$.

continuous culture. Increasing the level of replacement of dietary starch with glycerol in the diet had a positive effect on nutrient digestibility while promoting a more glucogenic fermentation profile.

\section{ACKNOWLEDGMENTS}

The authors thank Phodé SA (Albi Terssac, France) for providing the dry glycerol product used in this experiment.

\section{REFERENCES}

Allison, M. J., M. P. Bryant, and R. N. Doetsch. 1962. Studies on the metabolic function of branched-chain volatile fatty acids, growth factors for ruminococci. I. Incorporation of isovalerate into leucine. J. Bacteriol. 83:523-532.

AOAC. 2005. Official Methods of Analysis. 18th ed. AOAC Int., Gaithersburg, MD.

Bargo, F., G. A. Varga, L. D. Muller, and E. S. Kolver. 2003. Pasture intake and substitution rate effects on nutrient digestion and nitrogen metabolism during continuous culture fermentation. J. Dairy Sci. 86:1330-1340.

Bergner, H., C. Kijora, Z. Ceresnakova, and J. Szakacs. 1995. In vitro studies on glycerol transformation by rumen microorganisms. Arch. Tierernahr. 48:245-256.

Bryant, M. P. 1973. Nutritional requirements of the predominant rumen cellulolytic bacteria. Fed. Proc. 32:1809-1813.

Carvalho, E. R., N. S. Schmelz-Roberts, H. M. White, P. H. Doane, and S. S. Donkin. 2011. Replacing corn with glycerol in diets for transition dairy cows. J. Dairy Sci. 94:908-916.

Chung, Y.-H., D. E. Rico, C. M. Martinez, T. W. Cassidy, V. Noirot, A. Ames, and G. A. Varga. 2007. Effects of feeding dry glycerin to early postpartum Holstein dairy cows on lactational performance and metabolic profiles. J. Dairy Sci. 90:5682-5691.

Crawford, R. J. Jr., W. H. Hoover, and P. H. Knowlton. 1980. Effects of solids and liquid flows on fermentation in continuous cultures. I. Dry matter and fiber digestion, VFA production and protozoa numbers. J. Anim. Sci. 51:975-985.

Donkin, S. S., S. L. Koser, H. M. White, P. H. Doane, and M. J. Cecava. 2009. Feeding value of glycerol as a replacement for corn grain in rations fed to lactating dairy cows. J. Dairy Sci. 92:5111-5119.

Eschenlauer, S. C. P., N. McKain, N. D. Walker, N. R. McEwan, C. J. Newbold, and R. J. Wallace. 2002. Ammonia production by ru- minal microorganisms and enumeration, isolation, and characterization of bacteria capable of growth on peptide and amino acids from the sheep rumen. Appl. Environ. Microbiol. 68:4925-4931.

Garton, G. A., A. K. Lough, and E. Vioque. 1961. Glyceride hydrolysis and glycerol fermentation by sheep rumen contents. J. Gen. Microbiol. 25:215-225.

Gorosito, A. R., J. B. Russell, and P. J. Van Soest. 1985. Effect of carbon- 4 and carbon-5 volatile fatty acids on digestion of plant cell wall in vitro. J. Dairy Sci. 68:840-847.

Griffiths, W. R. 1952. Treatment of pregnancy toxaemia in ewes by oral administration of glycerol. Vet. Rec. 64:734.

Hobson, P. N., and S. O. Mann. 1961. The isolation of glycerol-fermenting and lipolytic bacteria from the rumen of the sheep. J. Gen. Microbiol. 25:227-240.

Hoover, W. H., T. K. Miller, S. R. Stokes, and W. V. Thayne. 1989. Effects of fish meals on rumen bacterial fermentation in continuous culture. J. Dairy Sci. 72:2991-2998.

Hungate, R. E. 1966. The Rumen and Its Microbes. Academic Press, New York, NY, and London, UK.

Johnson, R. B. 1954. The treatment of ketosis with glycerol and propylene glycol. Cornell Vet. 44:6-21.

Khalili, H., T. Varvikko, V. Toivonen, K. Hissa, and M. Suvitie. 1997. The effects of added glycerol or unprotected free fatty acids or a combination of the two on silage intake, milk production, rumen fermentation and diet digestibility in cows given grass silage based diets. Agr. Food Sci. in Finland 6:349-362.

Kijora, C., H. Bergner, K.-P. Götz, J. Bartelt, J. Szakács, and A. Sommer. 1998. Research note: Investigation on the metabolism of glycerol in the rumen of bulls. Arch. Tierernahr. 51:341-348.

Leng, R. A., and J. V. Nolan. 1984. Nitrogen metabolism in the rumen. J. Dairy Sci. 67:1072-1089.

Lin, E. C. 1977. Glycerol utilization and its regulation in mammals. Annu. Rev. Biochem. 46:765-795.

Ma, F., and M. A. Hanna. 1999. Biodiesel production: A review. Bioresour. Technol. 70:1-15.

Mach, N., A. Bach, and M. Devant. 2009. Effects of crude glycerin supplementation on performance and meat quality of Holstein bulls fed high-concentrate diets. J. Anim. Sci. 87:632-638.

McDougall, E. I. 1948. Studies on ruminant saliva. I. The composition and output of sheep's saliva. Biochem. J. 43:99-109.

NRC. 2001. Nutrient Requirements of Dairy Cattle. 7th rev. ed. Natl. Acad. Sci., Washington, DC.

Remond, B., E. Souday, and J. P. Jouany. 1993. In vitro and in vivo fermentation of glycerol by rumen microbes. Anim. Feed Sci. Technol. 41:121-132.

Robson, D. S. 1959. A simple method for constructing orthogonal polynomials when the independent variable is unequally spaced. Biometrics 15:187-191. 
Roger, V., G. Fonty, C. Andre, and P. Gouet. 1992. Effects of glycerol on the growth, adhesion, and cellulolytic activity of rumen cellulolytic bacteria and anaerobic fungi. Curr. Microbiol. 25:197-201.

SAS Institute. 1999. SAS/STAT User's Guide: Statistics. Version 8 ed. SAS Inst. Inc., Cary, NC.

Schröder, A., and K.-H. Südekum. 1999. Glycerol as a by-product of biodiesel production in diets for ruminants. Paper no. 241 in New Horizons for an Old Crop. Proc. 10th Int. Rapeseed Congr., Canberra, Australia. N. Wratten and P. A. Salisbury, ed. The Regional Institute Ltd., Gosford, New South Wales, Australia.

Seal, C. J., and C. K. Reynolds. 1993. Nutritional implications of gastrointestinal and liver metabolism in ruminants. Nutr. Res. Rev. 6:185-208

Trabue, S., K. Scoggin, S. Tjandrakusuma, M. A. Rasmussen, and P. J. Reilly. 2007. Ruminal fermentation of propylene glycol and glycerol. J. Agric. Food Chem. 55:7043-7051.

Van Soest, P. J. 1982. Fecal composition, mathematics of digestion balances and markers. Pages 39-57 in Nutritional Ecology of the Ruminant. O \& B Books Inc., Corvallis, OR.
Van Soest, P. J., J. B. Robertson, and B. A. Lewis. 1991. Methods for dietary fiber, neutral detergent fiber, and nonstarch polysaccharides in relation to animal nutrition. J. Dairy Sci. 74:3583-3597.

Vázquez-Añón, M., T. Cassidy, P. McCullough, and G. A. Varga. 2001. Effects of Alimet on nutrient digestibility, bacterial protein synthesis, and ruminal disappearance during continuous culture. J. Dairy Sci. 84:159-166.

Wang, C., Q. Liu, W. J. Huo, W. Z. Yang, K. H. Dong, Y. X. Huang, and G. Guo. 2009. Effects of glycerol on rumen fermentation, urinary excretion of purine derivatives and feed digestibility in steers. Livest. Sci. 121:15-20.

Yang, C.-M. J., and G. A. Varga. 1989. Effect of three concentrate feeding frequencies on rumen protozoa, rumen digesta kinetics, and milk yield in dairy cows. J. Dairy Sci. 72:950-957.

Zinn, R. A., and F. N. Owens. 1986. A rapid procedure for purine measurement and its use for estimating net ruminal protein synthesis. Can. J. Anim. Sci. 66:157-166. 